\title{
Preparation of nickel manganese oxide modified ni foam for anode catalyst direct urea fuel cell
}

\author{
Yola Yolanda ${ }^{1}$, Muhammad Ridwan ${ }^{1}$, Jong Wook Hong ${ }^{2}$ and Tribidasari Anggarainum \\ Ivandini $^{1 *}$ \\ ${ }^{1}$ Department of Chemistry, Faculty of Mathematics and Natural Sciences, Universitas Indonesia, \\ Kampus UI Depok, Depok 16424, Indonesia. \\ ${ }^{2}$ Department of Chemistry, University of Ulsan 12 Tekeunosaneop-ro 55beon-gil, Nam-gu, Ulsan, \\ Korea.
}

\begin{abstract}
Renewable energy is known as environmentally friendly, such as fuel cells. Nickel is regarded as one of the most promising transition metals to be applied as an electrocatalyst in fuel cell application due to its high catalytic activity. However, the modification of nickel is required to decrease its overpotential. In the present study, the $\mathrm{NiMn}_{2} \mathrm{O}_{4} / \mathrm{Ni}$-foam was prepared for an anode catalyst in the direct urea fuel cell. The $\mathrm{NiMn}_{2} \mathrm{O}_{4} / \mathrm{Ni}$ foam was synthesized through the hydrothermal method at $180^{\circ} \mathrm{C}$ for $24 \mathrm{~h}$ using $\mathrm{Mn}\left(\mathrm{NO}_{3}\right)_{2} .6 \mathrm{H}_{2} \mathrm{O}$ and $\mathrm{Ni}\left(\mathrm{NO}_{3}\right)_{2} \cdot 6 \mathrm{H}_{2} \mathrm{O}$ solutions as the precursors in the presence of urea. During the reaction, $\mathrm{Ni}$ foam was placed in the solution to undergo the reaction inside the porous of the Ni-foam. Cyclic voltammetry of the prepared $\mathrm{NiMn}_{2} \mathrm{O}_{4} / \mathrm{Ni}$-foam electrode in a $2 \mathrm{M} \mathrm{KOH}$ solution and 0.33 $M$ urea showed good maximum current density at $206 \mathrm{~mA} \mathrm{~cm}{ }^{-2}$. Furthermore, the prepared electrode was examined in a direct urea fuel cell with a solution containing $2 \mathrm{M} \mathrm{KOH}$ and $0.33 \mathrm{M}$ urea in the anode chamber and a solution containing $2 \mathrm{M} \mathrm{H}_{2} \mathrm{O}_{2}$ and $2 \mathrm{M} \mathrm{H}_{2} \mathrm{SO}_{4}$ in the anode chamber. A power density of $0.304 \mathrm{~mW} \mathrm{~cm}{ }^{-2}$ was achieved, indicating the prepared electrode is promising to be developed for a catalyst in a direct urea fuel cell.
\end{abstract}

\section{Introduction}

The fuel cell is a renewable energy source that attracts the attention of researchers because it holds several advantages, such as environmentally friendly, less production of carbon emissions, and less noise. The fuel cell converts chemical energy into electrical energy [1]. The system was operated by using hydrogen-rich chemical compounds such as methanol, ethanol, and urea [2]. Urea is one of the promising fuel sources because it is non-toxic, stable, non-flammable, and easy to obtain [2], [3]. However, urea has a notable disadvantage as a fuel source due to the low power density produced. Thus, a catalyst is needed to increase the urea power density and to achieve a higher performance to the fuel cell system.

\footnotetext{
*Corresponding author: ivandini.tri@sci.ui.ac.id
} 
Nickel is a transition metal that has been widely utilized as an electrocatalyst in a fuel cell system due to its high activity [4], [5]. However, nickel has a disadvantage due to its high overpotential in electro-oxidation of urea, which can reduce the performance of the fuel cell [6]. The modification of nickel is required to reduce the overpotential and to increase the overall effectiveness of the fuel cell.

It was reported that modification of nickel with manganese oxide succeeded in reducing the urea oxidation potential [2]. In the present study, nickel manganese oxide was modified in nickel foam (Ni-foam). Ni-foam has a high surface area and good mass transfer property because it has a porous structure. Several studies described the modification of the composition of nickel nanowire prepared by the electrodeposition method [2], showing high urea oxidation activity and high stability. Fuel cells with urea raw material are composed of electro-oxidation urea in the anode and electro-reduction oxidants such as oxygen, air, or hydrogen peroxide in the cathode. Overall the reactions that occur in this fuel cell are as follows [7]:

Anode:

$\mathrm{CO}\left(\mathrm{NH}_{2}\right)_{2}+8 \mathrm{KOH} \leftrightarrow \mathrm{K}_{2} \mathrm{CO}_{3}+6 \mathrm{H}_{2} \mathrm{O}+\mathrm{N}_{2}+6 \mathrm{~K}^{+}+6 \mathrm{e}^{-} \quad \mathrm{E}^{\circ}=-0.746 \mathrm{~V}$ vs SHE Cathode :

$3 \mathrm{H}_{2} \mathrm{O}_{2}+3 \mathrm{H}_{2} \mathrm{SO}_{4}+6 \mathrm{e}^{-} \leftrightarrow 6 \mathrm{H}_{2} \mathrm{O}+3 \mathrm{SO}_{4}{ }^{2-}$ Overall:

$\mathrm{CO}\left(\mathrm{NH}_{2}\right)_{2}+3 \mathrm{H}_{2} \mathrm{O}_{2}+3 \mathrm{H}_{2} \mathrm{SO}_{4}+8 \mathrm{KOH} \rightarrow \mathrm{K}_{2} \mathrm{CO}_{3}+3 \mathrm{~K}_{2} \mathrm{SO}_{4}+\mathrm{N}_{2}+12 \mathrm{H}_{2} \mathrm{O}$

$\mathrm{E}_{\text {cell }}^{\circ}=2.509 \mathrm{~V}$

In this research, a catalyst to increase the power density of urea fuel cell was created by depositing nickel manganese oxide in the nickel foam porous.

\section{Material and Method}

\subsection{Materials}

Ethanol and acetone were retrieved from Daejung, while $\mathrm{Mn}\left(\mathrm{NO}_{3}\right)_{2} \cdot 6 \mathrm{H}_{2} \mathrm{O}$ was obtained from Alfa Aesar. $\mathrm{Ni}\left(\mathrm{NO}_{3}\right)_{2} \cdot 6 \mathrm{H}_{2} \mathrm{O}$, urea, and $\mathrm{H}_{2} \mathrm{O}_{2}$ were purchased from Sigma-Aldrich. Finally, $\mathrm{KOH}$ and $\mathrm{H}_{2} \mathrm{SO}_{4}$ were purchased from Samchun Chemicals and Merck, respectively.

\subsection{Synthesis of the electrode}

First, the $1 \times 1 \mathrm{~cm}$ size nickel foam was sonicated in acetone, ethanol, and deionized water consecutively for $30 \mathrm{~min}$ each. Separately, $2.5 \mathrm{mmol} \mathrm{Mn}\left(\mathrm{NO}_{3}\right)_{2} .6 \mathrm{H}_{2} \mathrm{O}, 2.5 \mathrm{mmol} \mathrm{Ni}$ $\left(\mathrm{NO}_{3}\right)_{2} \cdot 6 \mathrm{H}_{2} \mathrm{O}$, and $7.5 \mathrm{mmol}$ urea were dissolved in $30 \mathrm{~mL}$ of distilled water. The solution was stirred with a magnetic stirrer for $30 \mathrm{~min}$ at $45^{\circ} \mathrm{C}$ (until homogeneous). The nickel foam and homogeneous solution were transferred into the autoclave and heated in the furnace at $180^{\circ} \mathrm{C}$ for $24 \mathrm{~h}$. The samples were then annealed at $400^{\circ} \mathrm{C}$ for $2 \mathrm{~h}$ in $\mathrm{Ar}$ atmosphere and named as $\mathrm{NiMn}_{2} \mathrm{O}_{4} / \mathrm{NF}$.

\subsection{Characterizations of the prepared electrode}

The X-ray diffraction (XRD) measurement was carried out by using a D/Max2500V/PC (Rigaku). Morphologies and the element distribution were investigated by field emission scanning electron microscope (SEM, JEOL JEM-7210F) equipped with an energy-dispersive $\mathrm{X}$-ray spectrum (EDS) analyzer. 


\subsection{Electrochemical measurements}

The prepared $\mathrm{NiMn}_{2} \mathrm{O}_{4} / \mathrm{NF}$, an $\mathrm{Hg} / \mathrm{HgO}$ system, and a Pt spiral were used as the working electrode, reference electrode, and counter electrode, respectively. Electrochemistry of the electrode was studied by using cyclic voltammetry technique in $2 \mathrm{M}$ aqueous $\mathrm{KOH}$ solutions with and without $0.33 \mathrm{M}$ urea in a potential range $0.064 \mathrm{~V}-0.669 \mathrm{~V}$ and a scan rate of 100 $\mathrm{mVs}^{-1}$. Meanwhile, the application for fuel cell was examined using chronoamperometry and chronopotentiometry for one hour in $2 \mathrm{M}$ aqueous $\mathrm{KOH}$ solutions and $0.33 \mathrm{M}$ urea with $\mathrm{N}_{2}$ gas in the anode and $2 \mathrm{M} \mathrm{H}_{2} \mathrm{O}_{2}$ and $2 \mathrm{M} \mathrm{H}_{2} \mathrm{SO}_{4}$ in the cathode.

\section{Results and discussion}

\subsection{Pretreatment of nickel foam}

Prior to modification, the nickel foam pretreatment was carried out to clean $\mathrm{Ni}$ foam from other compounds present in nickel foam, such as sulfides and oxides [8]. The absence of impurities in the nickel foam was expected to produce clean Ni-foam as a template for nickel manganese oxide to grow. Various pretreatment methods were carried out using $\mathrm{HCl}$ and acetone. Electrochemical studies were carried out at a scan rate of $20 \mathrm{mV} / \mathrm{s}$ in a $2 \mathrm{M} \mathrm{KOH}$ solution with a potential current at $-0.064-0.669 \mathrm{~V}$. Treatment with acetone provides better results compared to a treatment with $\mathrm{HCl}$, as indicated by the absence of peak oxidation and reduction as shown in Fig. 1a.

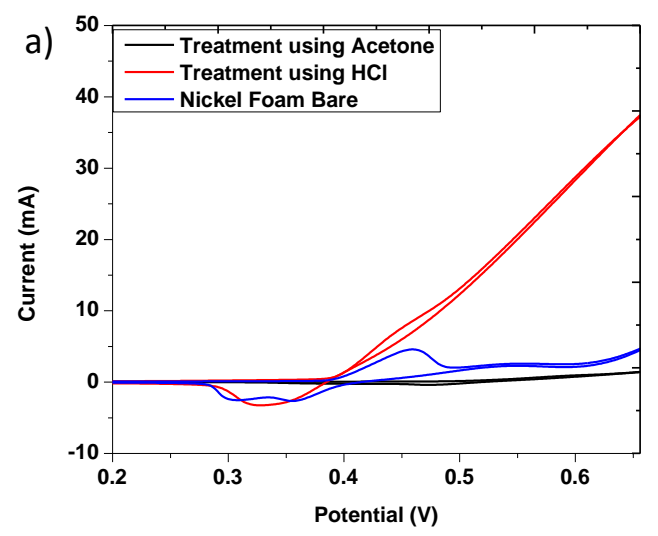



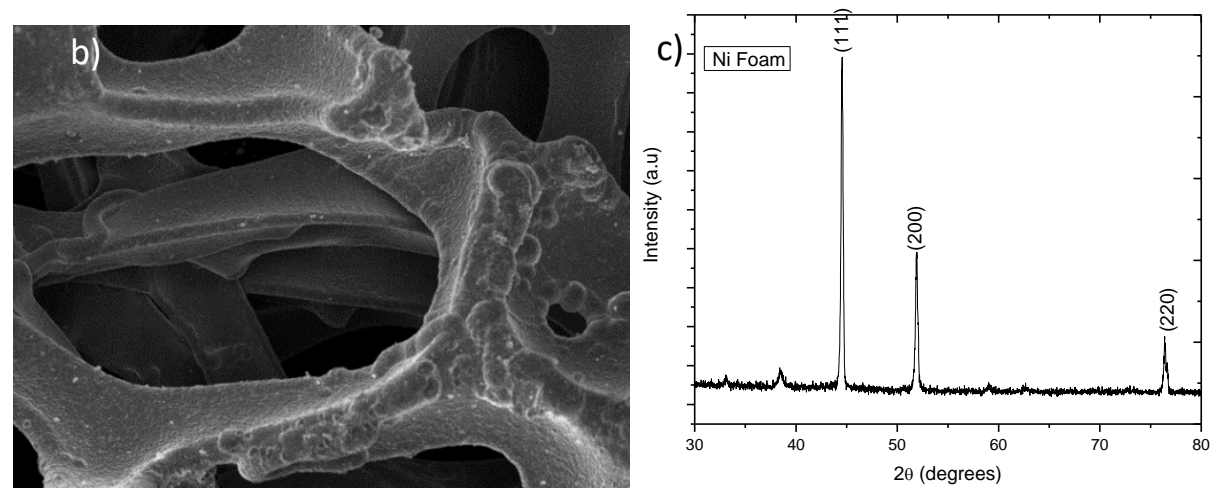

Fig. 1. (a) Cyclic voltammetry of Ni foam treated by various methods together with (b) related SEM image and (b) XRD spectrum of the cleaned $\mathrm{Ni}$ foam

The SEM result of the cleaned nickel foam (Fig. 1b) confirmed that the nickel foam has three dimensions structure with many pores and a rough surface. The physical properties produced in this study were very similar to those reported by [9]. Further characterization with XRD (Fig. 1c) shows that nickel foam observed three diffraction peaks of $2 \theta$, namely $44.5^{\circ}, 51.9^{\circ}$, and $76.4^{\circ}$ on the index (111), (200), and (220), which corresponded to the reference diffraction values of PDF \# 04-0850 [9].

\subsection{Synthesis and characterization of Nickel Manganese Oxide}

SEM characterization was carried out to observe the morphological information of synthesized nickel manganese oxide. Fig. 2(a) shows that the examples of synthesized $\mathrm{NiMn}_{2} \mathrm{O}_{4}$ particles were similar to the $\mathrm{NiMn}_{2} \mathrm{O}_{4}$ structure reported by [10] with the structure form as a bipyramidal (octahedral) nanoplate of around $100 \mathrm{~nm}$ sizes. Further characterization with XRD Fig. 2(a) shows diffraction peaks $2 \Theta$ at $33.60^{\circ}, 35.78^{\circ}, 36.71^{\circ}$, $43.63^{\circ}, 56.33^{\circ}, 57.82^{\circ}, 60.72^{\circ}$, and $74.08^{\circ}$ which are corresponded to the index (220), (311), (222), (400), (422), (511), (440) and (622), respectively. Comparison of all peaks with $\mathrm{NiMn}_{2} \mathrm{O}_{4}$ (JCPDS 71-0852) [10], indicating that $\mathrm{NiMn}_{2} \mathrm{O}_{4}$ has been successfully formed.
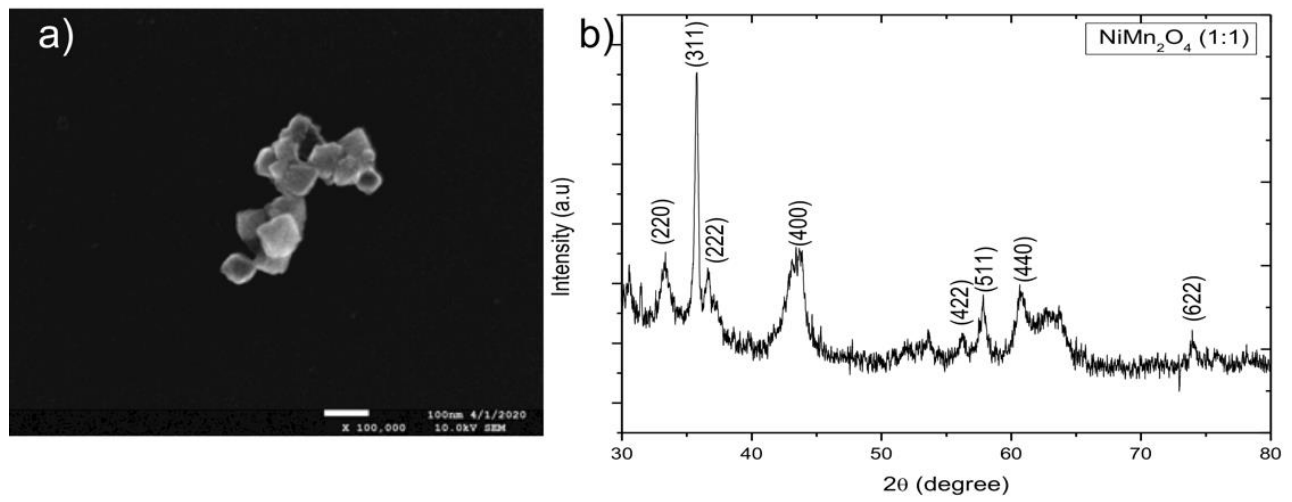

Fig. 2. (a) SEM Image of free crystal of $\mathrm{NiMn}_{2} \mathrm{O}_{4}$ with its $\mathrm{XRD}$ spectrum shown in (b) 


\subsection{Synthesis of $\mathrm{NiMn}_{2} \mathrm{O}_{4}$-modified nickel foam and its application}

Fig. 3a show the photographs of nickel foams before (left) and after (right) the modification with nickel manganese oxide. It can be seen that after the hydrothermal and calcination stages, the color of nickel foam was changed from silver to darker tone, indicating that $\mathrm{NiMn}_{2} \mathrm{O}_{4}$ has been deposited on Ni-foam. Similar conditions have also been explained by Sun et al. [11].

SEM characterizations carried out to investigate the morphology and element composition of nickel manganese oxide particles that have been deposited on Ni-foam shows nickel manganese oxide was successfully deposited on the Ni-foam as well (Fig. 3b and 3c). The SEM image in Fig. 3b shows the nickel manganese oxide form as groups of plate particles with a size between $1-10 \mu \mathrm{m}$, while further magnification (Fig. 3c) shows that the groups containing nanoplates with bipyramidal or octahedral structure with the size between $100-10 \mu \mathrm{m}$. It seems that agglomeration was occurred during the nickel manganese oxide formation inside the nickel foam porous. Meanwhile, EDS characterization showed that elemental distributions of nickel, manganese, and oxygen observed high nickel concentrations due to the use of nickel foam as the support. The percent of weight (wt) for $\mathrm{Ni}, \mathrm{Mn}, \mathrm{O}$ of $85 \%, 0.2 \%$, and $14.8 \%$, respectively, were observed. 

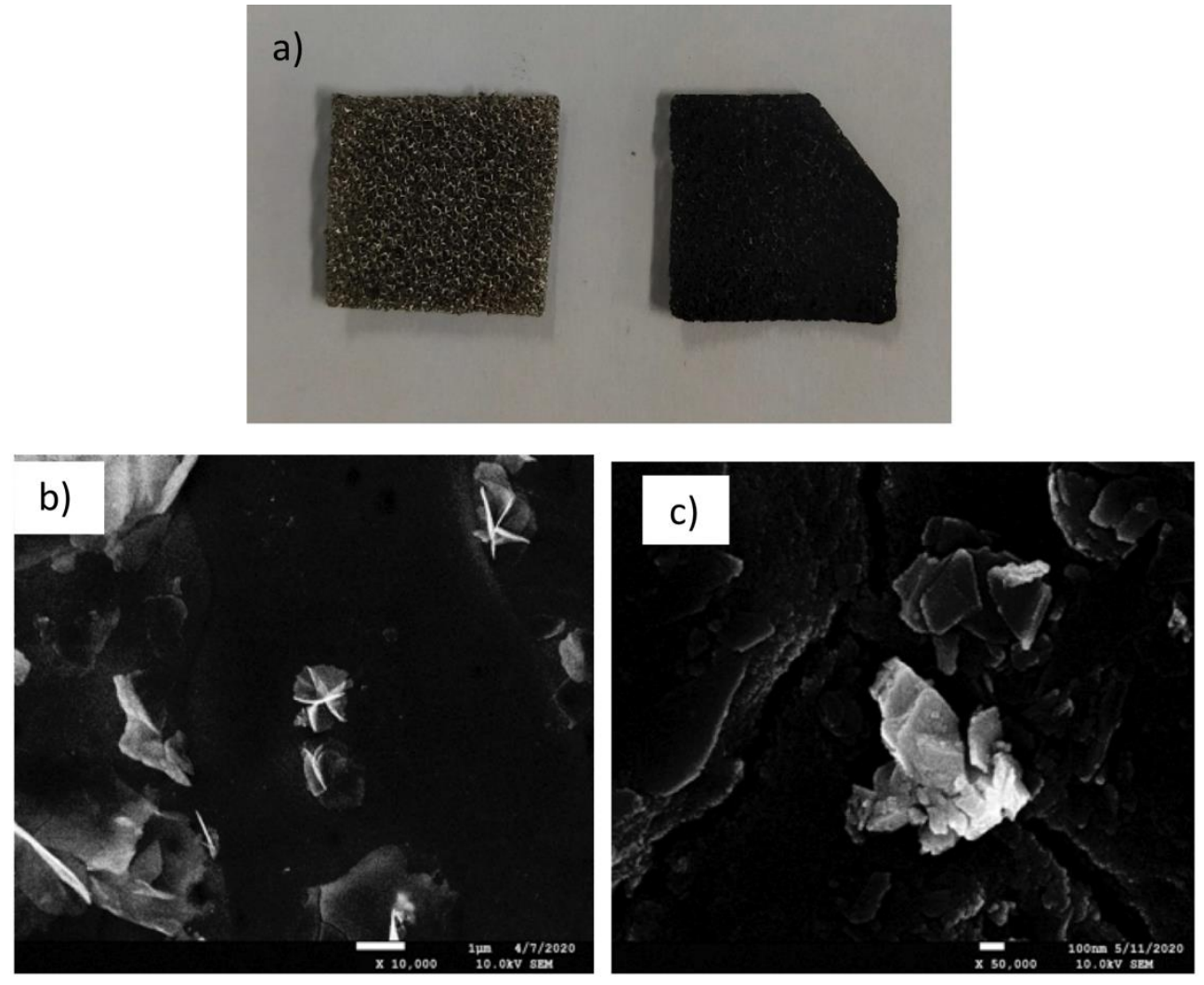

Fig. 3 (a) Photograph of nickel foam before (left) and after (right) modification with $\mathrm{NiMn}_{2} \mathrm{O}_{4}$ with SEM characterizations of the modified nickel form with (b) 10,000 and (c) 50,000 times of magnifications

Cyclic voltammograms (CV) of the prepared electrode in $2 \mathrm{M} \mathrm{KOH}$ is shown in Fig. 4. The $\mathrm{CV}$ shows the oxidation and reduction reactions of the modified nickel foam. The oxidation peak was observed between the potential area of +0.40 and $0.43 \mathrm{~V}$ (vs. SCE), while the reduction peak was in the potential region between +0.29 and $+0.34 \mathrm{~V}$ (vs. SCE). The oxidation peak was proposed due to the oxidation of $\mathrm{Ni}^{2+}$ to $\mathrm{Ni}^{3+}$, whereas the reduction peak was from $\mathrm{Ni}^{3+}$ reduction to $\mathrm{Ni}^{2+}$ [1], [12]. In the $\mathrm{CV}$, peak widening was also observed, indicated that the $\mathrm{NiMn}_{2} \mathrm{O}_{4} / \mathrm{Ni}$-foam electrode has a higher active side than $\mathrm{Ni}$-foam. In the presence of urea, the oxidation peak shifted to the potential more than $0.6 \mathrm{M}$. The increase of the potential also enhanced the current responses, reaction in the CV result. This indicated that manganese oxide could influence the nickel oxidation-reduction reactions in the urea solution. Based on the CV result, the maximum current density of $\mathrm{NiMn}_{2} \mathrm{O}_{4} / \mathrm{Ni}$-foam in the presence of in $2 \mathrm{M} \mathrm{KOH}$ and $0.33 \mathrm{M}$ urea solution was observed at $206.453 \mathrm{~mA} \mathrm{~cm}^{-2}$. 


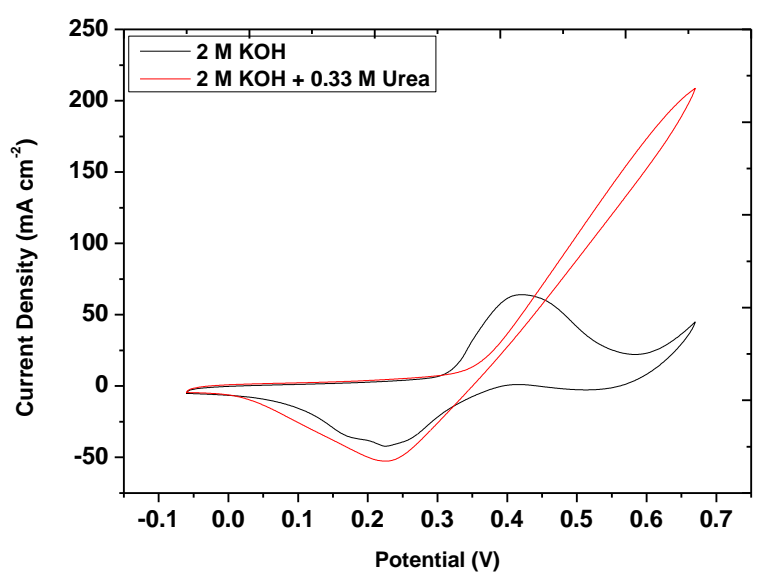

Fig. 4. $\mathrm{CV} \mathrm{NiMn} 2 \mathrm{O}_{4} / \mathrm{Nickel}$ Foam in $2 \mathrm{M} \mathrm{KOH}$ with and without the presence of $0.33 \mathrm{M}$ urea

The urea fuel cell application test was carried out using a solution containing $2.0 \mathrm{M} \mathrm{KOH}$ and $0.33 \mathrm{M}$ urea in the anode chamber and a solution containing $2.0 \mathrm{M} \mathrm{H}_{2} \mathrm{O}_{2}$ and $2.0 \mathrm{M}$ $\mathrm{H}_{2} \mathrm{SO}_{4}$ in the cathode chamber. The measurements were performed using chronoamperometry and chronopotentiometry each for one hour to identify the produced power density. A fairly good average power density at $0.304 \mathrm{~mW} / \mathrm{cm}^{-2}$ was achieved. Accordingly, although it can be concluded that the $\mathrm{NiMn}_{2} \mathrm{O}_{4} / \mathrm{Ni}$-foam electrode can be applied as a catalyst for fuel cell application, some improvement is required, including the optimum size of the modified particles as well as its distribution inside the nickel foam porous.

\section{Conclusion}

Nickel manganese oxide was successfully deposited in the porous of nickel foam using the hydrothermal method as proven by EDS-XRD characterization. The SEM image affirmed that the plate structure of $\mathrm{NiMn}_{2} \mathrm{O}_{4}$ nanoparticles was bipyramidal (octahedral)-like. $\mathrm{NiMn}_{2} \mathrm{O}_{4} / \mathrm{Ni}$-foam provides a fairly good performance as an anode catalyst in direct urea fuel cells with the resulting power density of $0.304 \mathrm{~mW} \mathrm{~cm}^{-2}$. Further research is needed to optimize the prepared material for the fuel cell catalyst.

\section{Acknowledgments}

The authors are sincerely grateful to the Universitas Indonesia for supporting this research through Hibah PUTI Q2 2020. No.NKB-1637/UN2.RST/HKP.05.00/2020.

\section{References}

1. E. T. Sayed et al., Direct urea fuel cells: Challenges and opportunities, J. Power Sources, 417, 159-175 (2019) https://doi.org/10.1016/j.jpowsour.2018.12.024

2. S. Periyasamy, P. Subramanian, E. Levi, D. Aurbach, A. Gedanken, and A. Schechter, Exceptionally Active and Stable Spinel Nickel Manganese Oxide Electrocatalysts for Urea Oxidation Reaction, ACS Appl. Mater. Interfaces, 8, 12176-12185 (2016) 
https://doi.org/10.1021/acsami.6b02491

3. R. Lan, S. Tao, and J. T. S. Irvine, A direct urea fuel cell - Power from fertilizer and waste, Energy Environ. Sci., 3, 438-441 (2010) DOI: 10.1039/b924786f

4. R. Lan and S. Tao, Preparation of nano-sized nickel as anode catalyst for direct urea and urine fuel cells, J. Power Sources, 196, 5021-5026 (2011) https://doi.org/10.1016/j.jpowsour.2011.02.015

5. R. H. Tammam and M. M. Saleh, On the electrocatalytic urea oxidation on nickel oxide nanoparticles modified glassy carbon electrode, J. Electroanal. Chem., 794, 189-196 (2017) https://doi.org/10.1016/j.jelechem.2017.04.023

6. W. Xu, H. Zhang, G. Li, and Z. Wu, Nickel-cobalt bimetallic anode catalysts for direct urea fuel cell, Sci. Rep., 4, (2014) DOI: 10.1038/srep05863

7. F. Guo et al., Enhancement of direct urea-hydrogen peroxide fuel cell performance by three-dimensional porous nickel-cobalt anode, J. Power Sources, 307, 697-704 (2016) https://doi.org/10.1016/j.jpowsour.2016.01.042

8. J. Zhang, Y. Sun, X. Li, and J. Xu, Fabrication of porous NiMn2O4 nanosheet arrays on nickel foam as an advanced sensor material for non-enzymatic glucose detection, Sci. Rep., 9, 1-13 (2019) DOI: 10.1038/s41598-019-54746-2

9. X. Hu, X. Tian, Y. W. Lin, and Z. Wang, Nickel foam and stainless steel mesh as electrocatalysts for hydrogen evolution reaction, oxygen evolution reaction and overall water splitting in alkaline media, RSC Adv., 9, 31563-31571 (2019) DOI: 10.1039/C9RA07258F

10. H. Pang et al., Facile synthesis of porous nickel manganite materials and their morphology effect on electrochemical properties, RSC Adv., 2, 5930-5934 (2012) DOI: $10.1039 / \mathrm{C} 2 \mathrm{RA} 20245 \mathrm{~J}$

11. Y. Sun, J. Zhang, X. Sun, and N. Huang, High-performance spinel NiMn2O4 microspheres self-assembled with nanosheets by microwave-assisted synthesis for supercapacitors, CrystEngComm, 22, 1645-1652 (2020) DOI: 10.1039/C9CE01623F

12. L. Sha et al., Hierarchical NiCo2O4 nanowire array supported on Ni foam for efficient urea electro-oxidation in alkaline medium, J. Power Sources, 412, 265-271, (2019) https://doi.org/10.1016/j.jpowsour.2018.11.059 